\title{
Mechanical Properties of Recycled Aggregate Self-Compacting High Strength Concrete Utilizing Waste Fly Ash, Cellular Concrete and Perlite Powders
}

\author{
Mohammed Abed $^{1 *}$, Rita Nemes ${ }^{1}$ \\ ${ }^{1}$ Department of Construction Materials and Technologies, \\ Faculty of Civil Engineering \\ Budapest University of Technology and Economics, \\ 1111 Budapest, Múegyetem rkp. 3, Hungary \\ * Corresponding author, e-mail: abed.mohammed@epito.bme.hu
}

Received: 14 September 2018, Accepted: 19 December 2018, Published online: 31 January 2019

\begin{abstract}
The sustainability of engineering products has become a basic requirement instead of a mere choice because the harmony between economic activity and the earth's ecosystem must be seriously considered. The influence of using three unprocessed waste powder materials as cement replacing materials (CRMs) and/or coarse recycled concrete aggregate (RCA) as a partial replacement of coarse natural aggregate (NA) on fresh and mechanical properties of self-compacting high-strength concrete (SCHSC) is investigated in this study. The activation index of the CRMs on the cement paste is tested as an initial step. The CRMs, namely, waste fly ash (WFA), waste perlite powder (WPP) and waste cellular concrete (WCC), are tested through 21 mixtures allocated by seven different series with three mixes of each. The mechanical properties of the 21 concrete mixes are determined after one, three and nine months of curing. Results of compressive strength, splitting tensile strength, flexural strength and modulus of elasticity are presented. This work shows that the mechanical and environmental performance of SCHSC can be improved by the replacement of NA by RCA of up to 50\% and the replacement of cement by WPP or WFA of up to 15\%. Using WCC is not recommended to be reached 15\% and using WFA is preferable to be with incorporating RCA rather than NA alone. Findings indicate that incorporating waste materials can be valuable in SCHSC, thereby potentially leading to an increasingly green environment and paving the way for advancements in sustainable construction.
\end{abstract}

\section{Keywords}

self-compacting high strength concrete (SCHSC), recycled concrete aggregate (RCA), waste fly ash (WFA), waste perlite powder (WPP), mechanical properties of concrete

\section{Introduction}

The introduction of the idea of sustainable development in the Rio Summit in 1992 [1] has not been in vain. It yielded a conscious recognition of the massive population growth witnessed in the last century and the forward-looking assessment of the advent of rapid urbanisation of developing countries. Work on sustainable technologies has been the focus in the early $21^{\text {st }}$ century. Meanwhile, concrete is the most widely used material in the construction industry because of its numerous benefits. This industry consumes large amounts of natural resources and emits tremendous $\mathrm{CO}_{2}$ quantities by cement production alone. Concrete, a composite material mainly composed of cement, aggregate and water, uses approximately 20 billion tons of raw materials annually [2]. Thus, aggregates that occupy around two-thirds of concrete volume have primarily been contributing to the increase in the world's aggregate demand to over 48 billion tons annually after 2010 [3], which can double in the next two to three decades if the present rate of consumption of aggregates and concrete continues [4]. Furthermore, aggregate processing, such as mining and transport operations, considerably increases carbon emission and energy consumption [5]. The construction and demolition (C\&D) waste generated by the construction sector cannot be eliminated easily by conventional means. This waste is dumped in landfill sites, where it negatively affects the environment, and space available for landfill is becoming increasingly scarce because of industrialisation and urbanisation. Means of using C\&D structural concrete 
application waste are urgently needed because of the excessive availability of such waste and the reduction in the cost of acquiring aggregates [6]. This development can allow the concrete industry to sustain continuous growth while reducing its carbon footprint and the resulting harm to the environment. The concept of using coarse recycled concrete aggregate (RCA) instead of virgin coarse natural aggregate (NA), which emerged in England during World War II, was initially used in pavement construction.

Researchers' investigations of recycling demolition waste concluded that RCA can be used to replace NA, and it paved the way for present usage of C\&D waste and promoting the usage of RCA in new and different concrete types. Various materials have become a necessity for a sustainable, green and innovative future. At the end of 2017, Kisku et al. [6], investigated hundreds of research papers about RCA and concluded that the use of mineral admixtures could enhance the properties of recycled aggregate concrete (RAC). They recommended further research regarding the addition of unconventional waste materials as cement replacing materials (CRMs) and about the long-term behaviour of RAC with respect to mechanical and durability properties. Meyer [7], investigated several waste materials used as CRMs and concluded that the use of RCA, along with the addition of a suitable percentage of industrial wastes, could be highly beneficial. The use of RCA as a replacement of NA for producing RAC has been extensively explored, but only a few studies have applied the concept of RCA on self-compacting concrete (SCC) [8,9]. Industrial application, which will be beneficial from the perspective of technical, financial, direct and indirect environmental, social and its properties, is also scarce [10-12]. For instance, in a past study, $\mathrm{CO}_{2}$ emission could be $24 \%$ lower than the control mix with the incorporation of RCA [13], but additional high range water reducing admixture (HRWRA) was needed for achieving SCC [14]. According to the literature, the contemporary orientation regarding recycling aligns with non-conventional utilisation of RCA either by use of special types of waste materials, such as pure (unprocessed) waste CRMs, and/ or by adopting these materials in special types of concrete, such as self-compacting high-strength concrete (SCHSC); Australia is a pioneer country that has been promoting this innovative utilisation [15].

\subsection{Waste Fly Ash (WFA)}

More than 300 individual minerals have been identified in various coal ash samples [16, 17]. Thus, the European Standards set several requirements and processes for treating waste fly ash (WFA) before its usage to optimise its fineness and thus to reduce its water demand and to improve its properties. These processes are classification, selection, sieving, drying, blending, grinding and carbon reduction, which are often costly and consume considerable amounts of energy [18]. Limited information is available about the utilisation of WFA. Snelson, Kinuthia and Hamood et al. [19-21], suggested that incorporating WFA as a partial replacement of cement would improve the mechanical and durability properties of concrete, and they used different expressions to denominate fly ash without any modification. These expressions were raw, unprocessed, low-quality, rejected and waste fly ash. Hamood et al. [21], investigated the utilisation of WFA in place of cement and found that increasing the replacement amount of cement by WFA reduced the flowability and mechanical properties at an early stage but improved the long-term properties. They recommended the use of WFA for producing SCC. Poon et al. [22], investigated the pozzolanic properties of WFA blended cement pastes. They observed that a high but not excessive water-to-binder $(\mathrm{w} / \mathrm{b})$ ratio could improve the reactivity of WFA owing to the high water absorption of WFA. Snelson and Kinuthia [19, 20], investigated the physical, mechanical and durability characteristics of concrete and cement paste using WFA, and their results confirmed the possibility of utilising WFA in various concrete works, although caution should be taken to avoid excessive cement replacement. Meanwhile, the incorporation of WFA in concrete from all aspects, especially the activation behaviour of the binder itself with time, has not been discussed.

\subsection{Waste Perlite Powder (WPP)}

Please Perlite is a natural glassy volcanic rock which contains high amounts of silicon dioxide and aluminium oxide with amorphous siliceous nature; therefore, it is a pozzolanic material that conforms to the specifications of pozzolanic materials [23, 24]. Over 2,650 thousand metric tons of perlite were produced worldwide in 2015. Several countries have perlite mines, and Hungary is one of the six countries which account for approximately $97 \%$ of the world production of perlite. This substance can be expanded 5-20 times its original volume when rapidly heated at $900{ }^{\circ} \mathrm{C}-1200{ }^{\circ} \mathrm{C}$ and then used in many construction areas. Expanded perlite can be used as a part of cement or aggregate in traditional cementitious materials or as a source material for geopolymers [25]. Using expanded perlite powder as a part of cement leads to a 
reduction in the strength of concrete and enhances the fresh properties [25, 26]. However, Yu, et al. [27], concluded the opposite. The usage of waste perlite powder (WPP) generated from the sawing of raw perlite rock without any processing has not been as seriously investigated in the literature as that of CRMs. Meanwhile, El Mir and Nehme [28], investigated the effect of the adoption of WPP as filler material in SCC and verified that its pozzolanic activity improved the filling capability and decreased the flowability of SCC.

By contrast, utilisation of waste cellular concrete powder (WCC) has not been clearly discussed in the literature, where the fine grade enhances the mechanical properties when it is used up to $10 \%$ as a replacement of cement. Our exercise investigated the fresh and hardened mechanical properties of SCHSC by incorporating different replacement amounts of unprocessed waste powder materials as CRMs and/or RCA as a partial replacement of NA at different ages to reduce NA and cement consumption in the concrete industry and to further promote the sustainable usage of SCHSC.

\section{Experimental work}

\subsection{Materials}

Binder: Ordinary Portland cement (OPC) CEM I $42.5 \mathrm{~N}$ was used to eliminate the effect of mineral admixtures and to investigate purely the effect of the incorporated waste powder materials on the properties of the concrete. Cement was replaced by the following waste powder materials:

- WFA collected from a coal power station in Hungary (Visonta coal-fired thermal power station) and delivered to the laboratory for use in the testing programme without any processing;

- WCC collected from ytong company in Hungary (Xella Magyarország Kft.);

- WPP is produced with high and low specific surface areas (WPP-c and WPP-s). WPP-c and WPP-s were used by $50 \%$ of each as WPP.

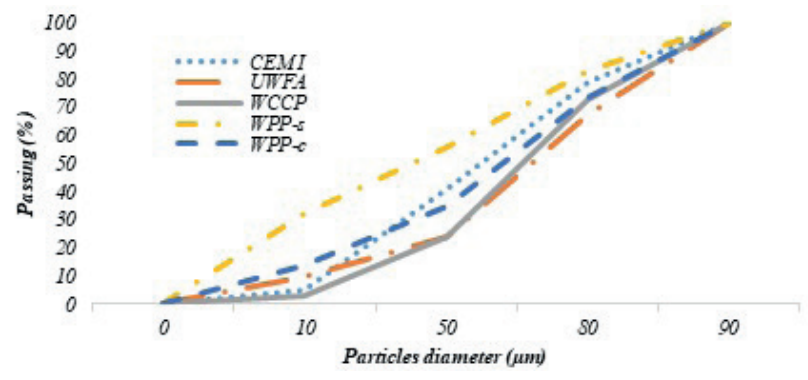

Fig. 1 Grading curves of cement and CRMs
The chemical, physical and mechanical properties of the cement and the proposed CRMs, which were tested in accordance with MSZ EN 196-2 and BS EN 525-12 $[29,30]$, are shown in Table 1. While Fig. 1. shows the sieve curves for the cement and the CRMs and depicts that WFA, WCC and WPP-c had larger particle size distributions than cement but WPP-s had a finer particle size distribution.

Aggregate: The first objective of the experiments was to partially replace the gravel fraction of aggregate with waste crushed concrete, and the sand fraction of aggregate $(0 / 4 \mathrm{~mm})$ was natural river quartz sand in all mixes. The coarse aggregate with $4 / 16 \mathrm{~mm}$ grading fraction was either natural quartz or RCA, which was crushed in the university's laboratory from concrete with an average compressive strength range of 28-33 MPa and then sieved through mechanical sieves to produce a $4 / 16 \mathrm{~mm}$ size fraction of the aggregate. The proportion of the fractions was $45 \%$ fine aggregate $(0 / 4 \mathrm{~mm})$ and $55 \%$ coarse aggregate $(4 / 16$ $\mathrm{mm})$. NA and RCA were tested to meet the requirements of BS EN 12620:2002+A1 [31]. The Los Angeles wear for RAC was relatively higher than that of NA owing to the low strength of the adhered mortar in RCA, where it was 36.11 for RCA and 26.3 for NA.

However, the water absorption of RCA after $24 \mathrm{~h}$ was $5.6 \%$, which required an extra amount of water to be added due to the RCA's porosity [32].

Table 1 Chemical compositions and physical properties of cement and CRMs

\begin{tabular}{|c|c|c|c|c|c|}
\hline $\begin{array}{l}\text { Measured } \\
\text { property }\end{array}$ & CEM I & WFA & WPP-c & WPP-s & WCC \\
\hline Density $\left(\mathrm{g} / \mathrm{cm}^{3}\right)$ & 3.02 & 2.15 & 2.33 & 2.33 & 1.96 \\
\hline $\begin{array}{l}\text { Specific surface } \\
\text { area }\left(\mathrm{cm}^{2} / \mathrm{g}\right)\end{array}$ & 3326 & 4323 & 843.3 & 4159 & 2513 \\
\hline Loss on ignition & 3.0 & 1.95 & 2.8 & 1.21 & 9.25 \\
\hline $\mathrm{SiO}_{2}$ & 19.33 & 43.02 & 73.8 & 73.2 & 54.28 \\
\hline $\mathrm{CaO}$ & 63.43 & 15.07 & 1.7 & 1.06 & 22.81 \\
\hline $\mathrm{MgO}$ & 1.45 & 3.14 & 0.11 & 0.2 & 1.15 \\
\hline $\mathrm{Fe}_{2} \mathrm{O}_{3}$ & 3.42 & 14.17 & 2.57 & 2.6 & 2.16 \\
\hline $\mathrm{Al}_{2} \mathrm{O}_{3}$ & 4.67 & 15.6 & 13.8 & 16.6 & 5.09 \\
\hline $\mathrm{SO}_{3}$ & 2.6 & 3.56 & - & - & 4.90 \\
\hline Chloride content & 0.04 & 0.02 & - & - & 0.02 \\
\hline Free $\mathrm{CaO}$ & 0.71 & 0.37 & - & - & - \\
\hline $\mathrm{K}_{2} \mathrm{O}$ & - & - & 4.01 & 3.5 & - \\
\hline $\mathrm{Na}_{2} \mathrm{O}$ & - & - & 2.66 & 1.5 & - \\
\hline $\mathrm{TiO}_{2}$ & - & - & 0.083 & 0.09 & - \\
\hline
\end{tabular}




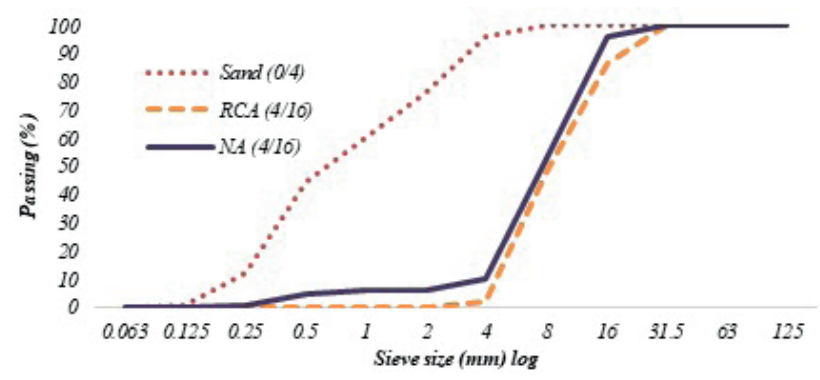

Fig. 2 Grading curves of NA and RCA
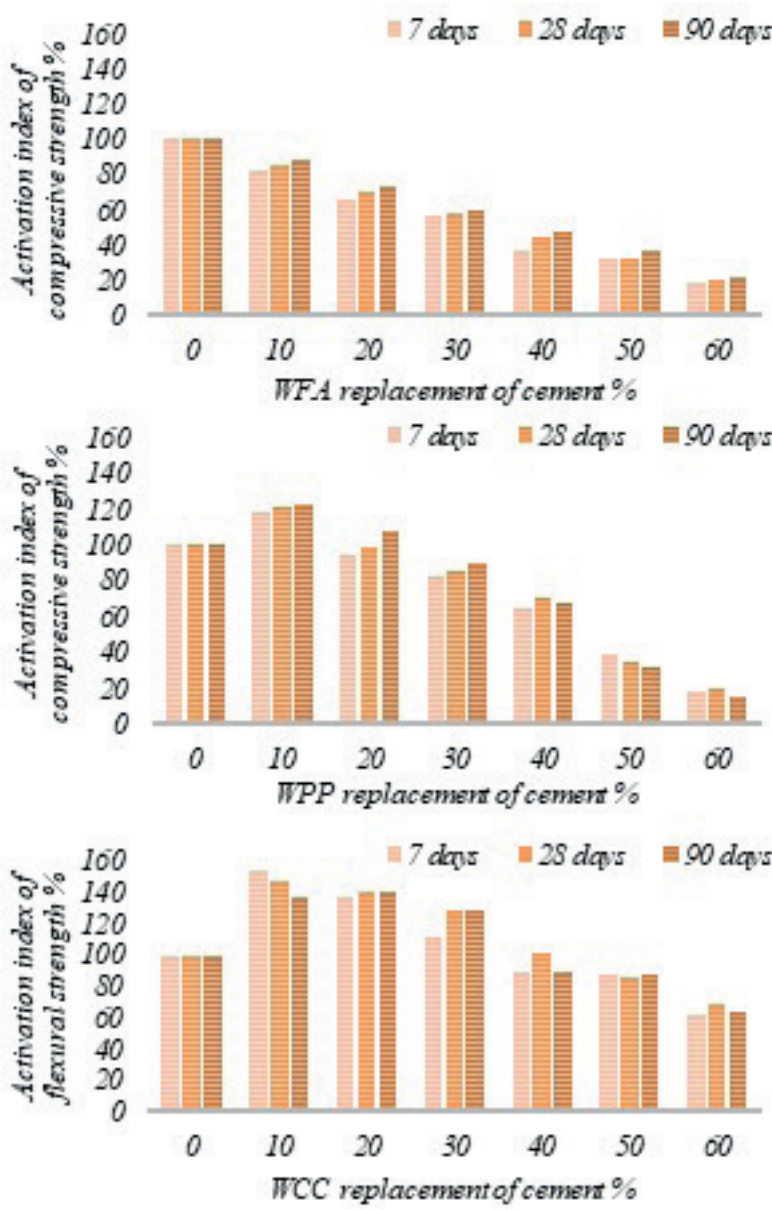

Fig. 3 Impact of CRMs on the activation index

Thus the water absorbed by RCA has been compensated by calculating the difference between its original water absorption capacity and the water content of aggregate when it used for mixing, which it is air dry status. All aggregate curves are shown in Fig. 2.

\subsection{Activation index and $\mathrm{X}$-Ray diffraction}

WFA, WPP and WCC were tested for the activation index of the compressive and flexural strength tests of cement paste samples (with $\mathrm{w} / \mathrm{b}$ ratio $=0.35$ ), with different incorporated amounts of the proposed CRMs (from $10 \%$ to $60 \%$ replacement). Activity index is expressed by the ratio of the strength of the cement paste mixture containing CRMs replacement and strength of the reference mixture (only OPC), which expresses the hydration rate of the CRMs [33]. The specimens were tested at three curing age of 7 , 28 , and 90 days. Replacing of cement by WFA decreases the compressive strength linearly and the activation index increases by time in case of all replacing amount, however, a significant reduction in the strength has been occurred by replacing the cement with more than $30 \%$ of cement. In the case of using WPP or WCC, the relationship is not so clear and they have a filler effect, their activation indexes were showed that an increase in the age of specimens incorporating WPP or WCC up to $30 \%$ increased the activity index. Otherwise, the behaviour of the activity index returned to decrease after 28 days, thereby rendering the applicability of replacement beyond $30 \%$ questionable.

Based on cement paste study, which is conducted to study the activation index of the proposed waste powder materials, cement was replaced by $15 \%$ and $30 \%$ waste powder materials. The activation indexes for the six paste mixtures for each waste powder material are presented in Fig. 3. WFA needs a long time for observing its hydration activity, and WCC showed better flexural strength activation index than compressive strength activation index.

The results of X-ray diffraction for the cement, WFA and WPP are shown in Fig. 4. A high absorption factor was recorded for iron, which meant: a long time was necessary for completing the hydration process of WFA. Considerable $\mathrm{SiO}_{2}$ was present in amorphous form and burned albite. The hydrated phase in the cement was gypsum (dehydrate), but it was anhydrite in WFA. The crystalline phases could be identified as follows:

- CEM I: $\mathrm{Ca}_{3} \mathrm{SiO}_{5}\left(\mathrm{C}_{3} \mathrm{~S}\right.$, alite, hatrurite) as main crystalline component; $\mathrm{Ca}_{2} \mathrm{SiO}_{4}\left(\mathrm{C}_{3} \mathrm{~S}\right.$, belite, larnite $)$ presence could not be excluded; - $\mathrm{CaSO}_{4} \cdot{ }_{2} \mathrm{H}_{2} \mathrm{O}\left(\mathrm{CSH}_{2}\right.$, gypsum); - $\mathrm{Ca}_{4} \mathrm{Al}_{2} \mathrm{Fe}_{2} \mathrm{O}_{10}\left(\mathrm{C}_{4} \mathrm{AF}\right.$, brownmillerite);

- WFA: - $\mathrm{a}-\mathrm{SiO}_{2}(\mathrm{~S}$, a-quartz) as main crystalline component; - $\mathrm{Fe}_{2} \mathrm{O}_{3}$ (F, hematite) also dominating crystalline component; - $\mathrm{CaSO}_{4}$ (CS, anhydrite); - plagioclase (feldspar, most probable heat-treated albite);

- WCC: - a- $\mathrm{SiO}_{2}$ (S, a-quartz) as the main crystalline component; - $\mathrm{CaSO}_{4}$ (CS, anhydrite); - hydrated mineral, called tobermorite 11A seemed to explain several diffraction peaks;

- WPP: - $\mathrm{SiO}_{2}$ (Ca-, Al-bearing cristoballite) as main crystalline component; - plagioclase (feldspar, most probable anortite); - occurrence of various zeolitically hydrated minerals could not be excluded. 


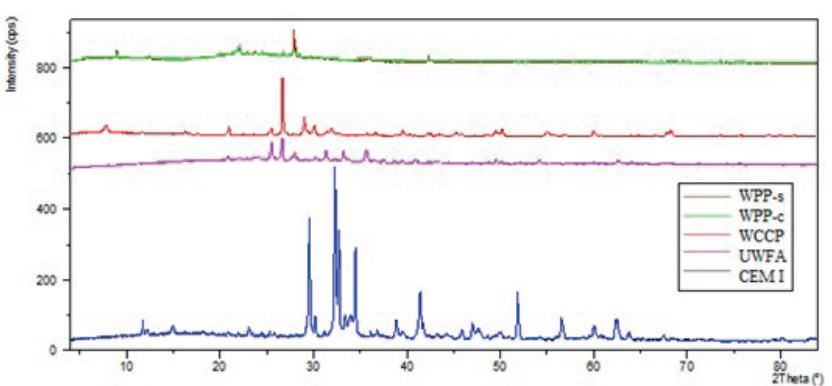

Fig. 4 Impact of CRMs on the activation index

Table 2 The sample matrix

\begin{tabular}{lcccc}
\hline Series \# & $\begin{array}{c}\text { Replacement } \\
\text { of cement }\end{array}$ & $\begin{array}{c}\text { replacement } \\
\text { of coarse } \\
\text { aggregate }\end{array}$ & $\begin{array}{c}\text { 25\% RCA } \\
\text { replacement } \\
\text { of coarse } \\
\text { aggregate }\end{array}$ & $\begin{array}{c}50 \% \text { RCA } \\
\text { replacement } \\
\text { of coarse } \\
\text { aggregate }\end{array}$ \\
\hline Series I & $0 \%$ & RA0 & RA25 & RA50 \\
Series II & $15 \%$ WFA & F15RA0 & F15RA25 & F15RA50 \\
Series III & $30 \% \mathrm{WFA}$ & F30RA0 & F30RA25 & F30RA50 \\
Series IV & $15 \% \mathrm{WCC}$ & C15RA0 & C15RA25 & C15RA50 \\
Series V & $30 \% \mathrm{WCC}$ & C30RA0 & C30RA25 & C30RA50 \\
Series VI & $15 \% \mathrm{WPP}$ & P15RA0 & P15RA25 & P15RA50 \\
Series VII & $30 \% \mathrm{WPP}$ & P30RA0 & P30RA25 & P30RA50 \\
\hline
\end{tabular}

\subsection{Mixing design and method}

Mixes with $500 \mathrm{~kg} / \mathrm{m}^{3}$ cement (powder) content and 0.35 $\mathrm{w} / \mathrm{b}$ ratio were kept constant throughout the experiments. The water absorbed by the aggregate was compensated by the addition of extra water to the mixture. Twenty-one concrete mixes of SCC incorporating RCA and different waste powder materials were designed. The mixes were divided into seven series, depending on the substitution ratios of cement and NA. The cement substitution ratios by waste powder materials were $0 \%, 15 \%$ and $30 \%$, whereas the NA substitution ratios by RCA were $0 \%, 25 \%$ and $50 \%$ by mass of NA. The aggregates in each case were mixed in such the proportion to obtain a first-class sieve curve. All mixtures were based on the authors' initial optimisation exercise for the project and are presented in Table 3 throughout the seven series, whose sample matrix is explained in Table 2.

A low $w / b$ ratio was used to achieve the rheological properties of SCC in which the mixture must be more workable than normal concrete. Thus, a considerable amount of HRWRA was required to achieve the necessary deformability and resistance to segregation at fresh state. 'Sika ViscoCrete-5 Neu' is a modified polycarboxylates aqueous solution, the same quantity of HRWRA was used for each series to investigate the actual effect of each replacement amount of RCA and waste powder materials on the fresh properties of SCC.
Table 3 Concrete mixing proportioning

\begin{tabular}{|c|c|c|c|c|c|c|c|}
\hline \multirow{4}{*}{$\begin{array}{l}\text { Name of } \\
\text { mixture }\end{array}$} & \multicolumn{7}{|c|}{ Proportions in $\mathrm{kg} / \mathrm{m}^{3}$} \\
\hline & \multirow{3}{*}{\begin{tabular}{l}
$Z$ \\
$n$ \\
\multirow{J}{*}{} \\
$\Xi$ \\
$\sum_{\text {J }}$
\end{tabular}} & \multirow{3}{*}{ 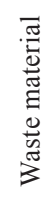 } & \multirow{3}{*}{$\begin{array}{c}\text { Fine } \\
\text { aggregate } \\
\text { Natural } \\
\text { Sand } \\
0 / 4\end{array}$} & \multicolumn{2}{|c|}{$\begin{array}{c}\text { Coarse } \\
\text { aggregate }\end{array}$} & \multirow{3}{*}{$\begin{array}{l}\underset{\alpha}{\alpha} \\
\underset{I}{z}\end{array}$} & \multirow{3}{*}{$\frac{\dot{ \pm}}{3}$} \\
\hline & & & & NA & $\mathrm{RCA}$ & & \\
\hline & & & & \multicolumn{2}{|c|}{$4 / 16$} & & \\
\hline \multicolumn{8}{|c|}{ Series I } \\
\hline RA0 & 500 & 0 & 783 & 939 & 0 & 1.5 & 175 \\
\hline RA25 & 500 & 0 & 783 & 704 & 230 & 1.5 & 175 \\
\hline RA50 & 500 & 0 & 783 & 470 & 460 & 1.5 & 175 \\
\hline \multicolumn{8}{|c|}{ Series II } \\
\hline F15RA0 & 425 & 75 & 767 & 920 & 0 & 2 & 175 \\
\hline F15RA25 & 425 & 75 & 767 & 690 & 226 & 2 & 175 \\
\hline F15RA50 & 425 & 75 & 767 & 460 & 251 & 2 & 175 \\
\hline \multicolumn{8}{|c|}{ Series III } \\
\hline F30RA0 & 350 & 150 & 751 & 901 & 0 & 3 & 175 \\
\hline F30RA25 & 350 & 150 & 751 & 475 & 221 & 3 & 175 \\
\hline F30RA50 & 350 & 150 & 751 & 451 & 442 & 3 & 175 \\
\hline \multicolumn{8}{|c|}{ Series IV } \\
\hline C15RA0 & 425 & 75 & 766 & 919 & 0 & 1.7 & 175 \\
\hline C15RA25 & 425 & 75 & 766 & 690 & 225 & 1.7 & 175 \\
\hline C15RA50 & 425 & 75 & 766 & 459 & 451 & 1.7 & 175 \\
\hline \multicolumn{8}{|c|}{ Series V } \\
\hline C30RA0 & 350 & 150 & 750 & 899 & 0 & 3.25 & 175 \\
\hline C30RA25 & 350 & 150 & 750 & 674 & 220 & 3.25 & 175 \\
\hline C30RA50 & 350 & 150 & 750 & 451 & 442 & 3.25 & 175 \\
\hline \multicolumn{8}{|c|}{ Series VI } \\
\hline P15RA0 & 425 & 75 & 774 & 928 & 0 & 3 & 175 \\
\hline P15RA25 & 425 & 75 & 774 & 697 & 228 & 3 & 175 \\
\hline P15RA50 & 425 & 75 & 774 & 464 & 455 & 3 & 175 \\
\hline \multicolumn{8}{|c|}{ Series VII } \\
\hline P30RA0 & 50 & 50 & 766 & 918 & 0 & 3.75 & 175 \\
\hline P30RA25 & 350 & 150 & 766 & 688 & 225 & 3.75 & 175 \\
\hline P30RA50 & 350 & 150 & 766 & 459 & 450 & 3.75 & 175 \\
\hline
\end{tabular}

Mixing was performed for a total mixing time of $4.5 \mathrm{~min}$ partitioned into three stages by using an electric concrete mixer. After each stage, the ingredients were manually mixed to achieve the highest homogeneity. Fig. 5. explains the mixing procedure. The samples were cast in steel molds of different sizes to obtain the standard specimens for each test. The specimens were cubes of $150 \times 150 \times 150 \mathrm{~mm}$ for the compressive strength tests, prisms of $70 \times 70 \times 250 \mathrm{~mm}$ for the modulus of elasticity and flexural strength tests and cylinders of $\varnothing 150 \times 300 \mathrm{~mm}$ for the splitting tensile strength tests. Table 4 shows the numbers and shapes of the test specimens for each mix. 


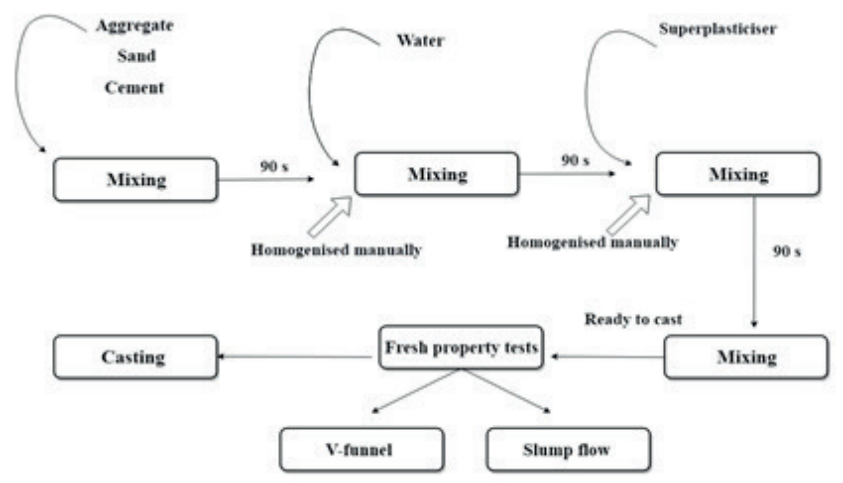

Fig. 5 Mixing procedure

Table 4 The numbers and forms of the test specimens for each mixture

\begin{tabular}{|c|c|c|c|c|}
\hline \multirow[b]{2}{*}{ Test } & \multirow[b]{2}{*}{ Specimen } & \multicolumn{3}{|c|}{ Age [month] } \\
\hline & & $\stackrel{0}{0}$ & $\stackrel{巳}{\Xi}$ &.$\Xi$ \\
\hline $\begin{array}{l}\text { Compressive } \\
\text { strength }\end{array}$ & Cube $(150 \times 150 \times 150 \mathrm{~mm})$ & 4 & 4 & 4 \\
\hline Flexural strength & Prism $(70 \times 70 \times 250 \times \mathrm{mm})$ & - & 4 & 4 \\
\hline $\begin{array}{l}\text { Splitting tensile } \\
\text { strength }\end{array}$ & Cylinder (Ø150-300 mm) & 4 & 4 & 4 \\
\hline $\begin{array}{l}\text { Modulus of } \\
\text { elasticity }\end{array}$ & Prism $(70 \times 70 \times 250 \times \mathrm{mm})$ & - & 6 & 6 \\
\hline
\end{tabular}

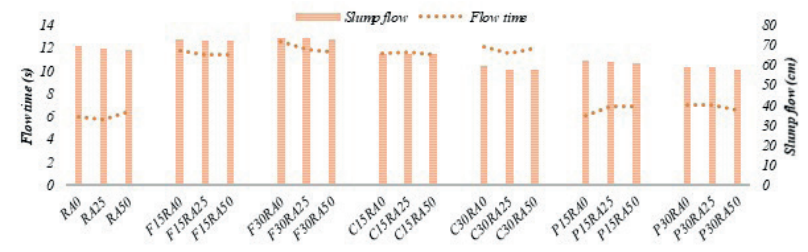

Fig. 6 Results of slump flow and V-funnel tests

All specimens were stored under lime-saturated water for seven days and then moved to laboratory ambient conditions $\left(20^{\circ} \mathrm{C} \pm 2{ }^{\circ} \mathrm{C}\right)$ until the time of the test.

The tests were conducted in different ages (one, three and nine months). A total of 420 prisms, 252 cubes and 252 cylinders were prepared.

\section{Results}

\subsection{Fresh properties}

To test the fresh properties of the mixtures, two different tests were applied in addition to the physical observations. The tests were slump flow and V-funnel tests. The same amount of HRWRA was optimised in the preparation stage of the mixtures to satisfy the EFNARC (2005) and to study the effects of RCA, WFA, WCC and WPP on the fresh properties of SCHSC. Fig. 6 shows the results obtained from the slump flow test (slump diameter in $\mathrm{cm}$ ) and $\mathrm{V}$-funnel test (flow time in $\mathrm{s}$ ). The recommended range in the EFNARC (2005) is 550-850 $\mathrm{mm}$ [34].
The results for Series I showed a decreasing tendency in the slump diameter as the amount of RCA increased; this finding was consistent with most research findings $[8,35$, 36]. However, the flow time increased with the addition of $50 \%$ RCA, which was mainly related to the shape and texture of RCA compared with the NA used. RCA had greater surface roughness and relatively more fine particles owing to the crushing processes. These factors affected the slump diameter and the flow time of the mixtures directly against increasing the amount of the involved RCA.

For Series II and III, the amount of HRWRA, flow diameter and flow time were increased compared with Series I, where the WFA negatively affected the fresh properties. The reduction in flowability might be caused by the high surface area and the high unburned carbon content of the added WFA. These parameters lead to the absorption of water, thereby resulting in decreased workability [20, 21]. Using WFA decreased the flow time owing to its capability to enhance the viscosity of concrete mixtures. Although the slump flow and V-funnel time decreased in Series VI and VII, the fresh properties were negatively affected when WPP was added, where the required amounts of HRWRA were increased considerably; this reduction in workability might be caused by the high surface area and absorption capacity of WPP [23, 28].

The effect of RCA was less than $3 \mathrm{~cm}$ for flow diameter and $1.5 \mathrm{~s}$ for flow time. However, increasing the amount of WCC or WFA increased the flow time owing to their amorphousness and water absorption capability if compared to OPC. This was not consistent with the result of a previous work, where the flowability increased in SCC incorporating processed fly ash [37]. All obtained measures of the slump flow and v-funnel tests in all series satisfied the EFNARC (2005) and the suggested determinations of previous literature.

\subsection{Mechanical properties}

The addition of RCA or any other mineral admixture will affect the mechanical properties of a hardened material positively or negatively, depending on its physical and chemical properties and the added proportion. The properties of RAC depend on many factors, such as $\mathrm{w} / \mathrm{b}$ ratio $[38,39]$, properties of RCA and interfacial transition zone (ITZ) [40], properties of adhered mortar and mother concrete [41], mixing approach and procedure [42], initial cement content [43], properties of added admixtures [44], and use of plasticisers [45]. The properties of RCA can be improved by different methods, one of them is the usage of admixtures [46]. 


\subsubsection{Compressive strength}

Compressive strength is the mostly investigated property of hardened concrete and influences the material's durability and performance. Researchers who investigated the effect of increasing RCA amount on the compressive strength by the same water-to-cement $(\mathrm{w} / \mathrm{c})$ ratio concluded that an increase in RCA amount leads to a decrease in compressive strength [47]. However, some researchers observed the opposite [48], the increase in strength is more significant on the long term and when mineral admixtures are used. A similar conclusion of altering behaviour can be drawn in case of SCC and high- [8, 49]. Compressive strength results after one, three and nine months for all series are presented in Fig. 7. The rate of strength gain of RAC was higher after one month than that of NA concrete [40, 50, 51], the adhered mortar on RCA could contain un-hydrated cement, which contributed to strength gain by the age [52].

Series I showed the effect on compressive strength by increases in the replacement amount of RCA in three ages; increasing the RCA dosage by up to $50 \%$ increased compressive strength, but the positive effect was not clear at the age of one month. This behaviour could be related to the high roughness, porosity and specific surface of the RCA, which contributed to better interconnection between RCA and the new mortar [53-55], good control of RCA grading and high grade of the concrete $[41,56]$.

The addition of up to $30 \%$ WFA in Series II and III enhanced several properties of RAC and achieved better strength performance than those with only NA. This behaviour could be related to the increased initial amount of water content in case of RAC because of the higher water absorption of RCA, which was used under air-dried condition could enhance the reactivity of the WFA and could contribute to improved strength $[57,58]$. The effect of the large particles of WFA on filling the inter-crack of RCA may lead to obtaining increased strength by ages, such as more than nine months. The improvement in strength was attributed to the pozzolanic activity of WFA at older ages.

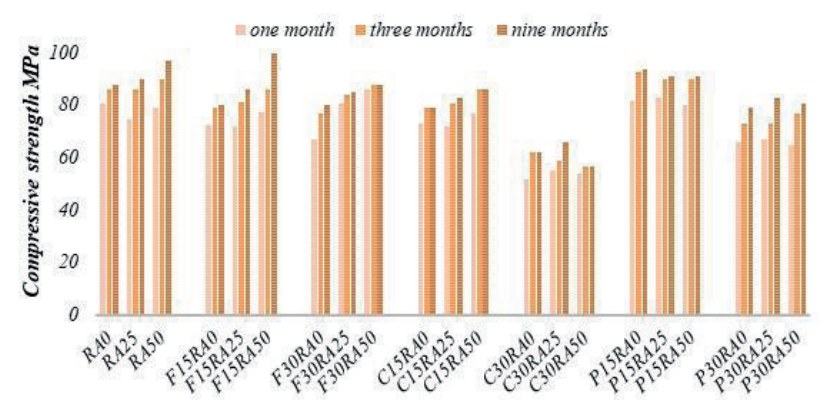

Fig. 7 Compressive strength results
WCC had low pozzolanic activity, or it could be slow, as shown in Series IV and V, where the strength of SCHSC decreased due to its large particles size, which decreased the pozzolanic activity; thus, its replacement percentage had to be less than 15\%. Using WPP had a noticeable pozzolanic activity, which had a positive effect on the compressive strength of NA concrete and RAC when it replaced the cement by up to $15 \%$. Series VI and VII show the results of replacing cement by WPP up to $15 \%$ and $30 \%$, respectively, which indicated that using WPP instead of cement had to be limited to up to $15 \%$ in NA concrete and RAC. The positive effect of WPP on the compressive strength of NA concrete was justified by its pozzolanic activity and the filler effect by both [27, 28]. The filler effect of WPP made the cement matrix denser owing to its finer particle size between cement particles [23], that could be the main reason for the positive effect of WPP on the strength of RAC.

\subsubsection{Splitting tensile strength}

Most of the studies concluded that splitting tensile strength decreases with an increase of RCA replacement ratio [59], however, Some studies concluded the opposite [60]. Using RCA for producing SCHSC proved its high capability to be better in tensile strength, whereas the major factors that affected tensile strength were the $\mathrm{w} / \mathrm{b}$ ratio and the chemical admixtures. The type of binding mortar influenced the development of splitting tensile strength more than the type of the aggregate in RAC, especially in the long run. Using WFA with RCA did not change the tensile strength significantly when it replaced the cement up to $30 \%$, which may require a longer age for its complete hydration $[48,59]$.

Using WCC affected the tensile strength negatively owing to its large particle size and low pozzolanic activity. The effect of the small particles of WPP improved the ITZ between aggregate and mortar, where using WPP had a positive effect on the splitting tensile strength of NA concrete when it replaced the cement up to $30 \%$ and up to $15 \%$ in RAC. WPP had a high absorption capacity with hollow composition inside, which contributed to gaining higher tensile strength at a long age.

Splitting tensile strength test results at one, three and nine months are presented for all series in Fig. 8. Results showed that the splitting tensile strength increased when RCA was added, thereby displaying trends similar to those of the compressive strength results. Series I recorded the highest values, and the others recorded less strength but in 
the same manner where these trends could be attributed to the same reasons as for compressive strength. The results for Series II and III were consistent with the achievements of Kou and Poon [52], whereas the results of the Series VI showed the highest splitting tensile strength at a long age.

\subsubsection{Flexural strength}

The decrease in flexural strength caused by an increase in RCA has been attributed by the extant research to poor interfacial bond quality, which develops between old adhered mortars and new mortars [52, 60, 61]. Series I showed a slight increase in the flexural strength with increased replacement amount of RCA. This finding was attributed mainly to the average water absorption capability of the RCA used, which directly enhanced the ITZ bond and the size aggregate distribution.

WFA also enhanced the flexural strength until the replacement of cement by $15 \%$ in the case of RAC, where it improved the ITZ owing to the high water absorption of the RCA. The increase of the grade of concrete had a positive relationship with the flexural strength [62], the produced concrete in the present paper was high-strength concrete, which contributed to the increase in flexural strength. Using WPP up to $30 \%$ improved the flexural strength significantly in cases of using NA or RCA up to $25 \%$, which enhanced the strength of the binder and the ITZ bond owing to the high fineness of the WPP. The finer the perlite particles, the greater the strength of the same mix designs [23]. In RAC, the fine particles of WPP also benefited for filling the micro-cracks in the RCA, caused by crushing. However, the use of WCC decreased the flexural strength similar to splitting tensile strength. Flexural strength test results for all seven series at three and nine months of curing age are presented in the Fig. 9. The ratio of tensile strength and compressive strength did not differ significantly from those of ordinary concrete in either case.

\subsubsection{Modulus of elasticity}

Most researchers have agreed on the negative effect of RCA on the modulus of elasticity; however, in the present study, the substitution of NA by RCA up to $50 \%$ showed a slight improvement, and using a high amount of HRWRA contributed to enhancing the modulus of elasticity and decreasing the known negative effect of RCA [63].

Pereira et al. [64], showed that the addition of a polycarboxylate-based HRWRA increased the modulus of elasticity of RAC by up to $33 \%$. The performance did not change significantly when $15 \%$ of cement was replaced by WFA

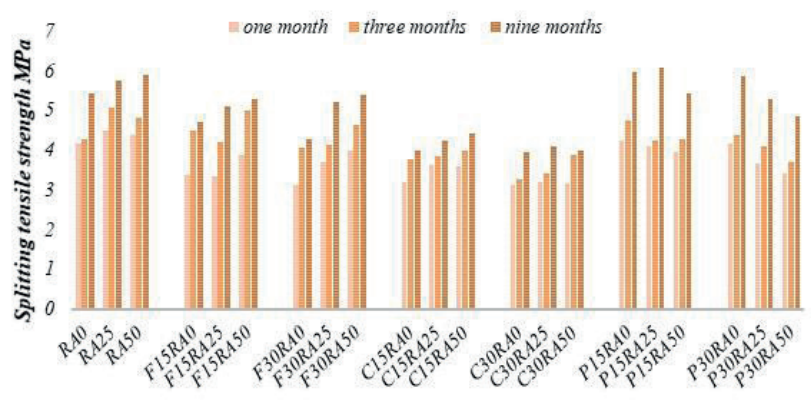

Fig. 8 Splitting tensile strength results

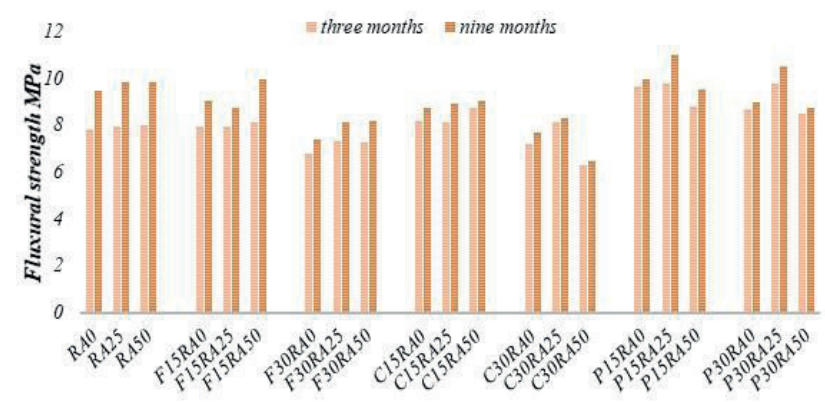

Fig. 9 Flexural strength results

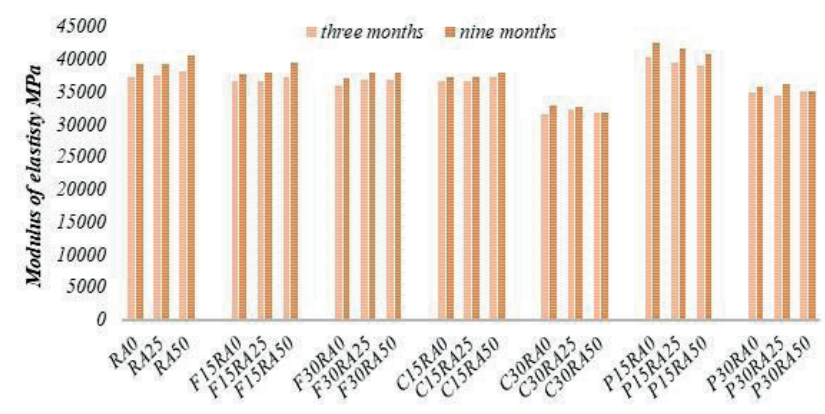

Fig. 10 Modulus of elasticity results

or WCC, where menial admixtures contributed to improving the ITZ bond but required a long time in some cases for enhancing the modulus of elasticity [59]. The modulus of elasticity was directly affected by the compressive and flexural strengths. WPP enhanced the modulus of elasticity when it replaced the cement by up to $15 \%$. This behaviour could be related to the chemical composition of WPP, which contained minerals and thus increased the ductility of the concrete. Fig. 10. shows the modulus of elasticity results for Series I, II, III, IV, V, VI and VII.

One of the most important points was that the using of RCA for producing SCHSC could improve the critical mechanical properties of concrete, such as modulus of elasticity, despite its large consumption of chemical admixtures which nearly offset the negative effect of RCA [64]. The mineral admixtures may be more effective with RCA than NA owing to the capability to enhance the properties of RAC by filling the pores of adhered mortar in 
RCA and decreasing the negative effect of cracks, which were produced by the crushing process for RCA. Thus, the ITZ was improved [65] and the strength was further enhanced with extended age [58].

Moreover, the non-usable portion of the waste material, which was incorporated in SCHSC, could perform as a filler to enhance the filling capability. Incorporating the properties of SCC and high-strength concrete could solve the difficulty of achieving the target strength alone in case of RAC, whereas Rahal [50], stated that RCA is not an appropriate choice for producing high-strength concrete owing to unreliability.

\section{Conclusions}

SCHSC is a special concrete that requires high flowability and strength. Chemical and mineral admixtures which enhance the properties of concrete must be used. The substitution of cement by unprocessed waste materials can produce an innovative, sustainable and green product in addition to improved performance capability. This research primarily aims to investigate the mechanical properties of SCHSC using RCA as a partial replacement of NA and three types of unprocessed waste powder materials as CRMs, namely, WFA, WCC and WPP, in short- and longterm investigations. The followings are the main findings.

1. The fresh concrete properties are negatively affected by using WFA, WCC and WPP. The HRWRA demand increases with an increase in the CRMs dosages, thereby achieving the same range of flowability.

2. Mechanical properties improve by increasing the replacement of RCA up to $50 \%$ of the total amount of coarse NA by mass, where this behavior is observed beyond the results of one month.

3. WFA negatively affects the mechanical properties in the case of NA concrete, unlike in the case of RAC.

4. Using up to $15 \%$ of WPP positively affects the mechanical properties in the case of NA concrete and RAC.

5. WFA and WPP have a clear pozzolanic activity, whereas WCC has a weak pozzolanic activity.

6. WCC negatively affects the mechanical properties of concrete, where it can be utilized with less replacement amount than $15 \%$.

7. SCHSC is one of the favorable choices for utilizing waste materials. The mechanical properties are effected positively or at least not significantly affected negatively by the additives.
8. Activation test of both WFA and WPP cement paste show they can replace cement in concrete by up to $30 \%$ of the cement mass, where the optimum value is $15 \%$.

9. SCHSC with RCA up to $50 \%$ and WFA up to $15 \%$ or SCHSC with RCA up to $25 \%$ and WPP up to $15 \%$ achieve optimal waste material dosages instead of either cement or NA. This observation applies in terms of not only good mechanical properties but also significant economic and environmental value.

10. Incorporating RCA in SCHSC can improve the mechanical properties and the modulus of elasticity, where it is not significantly affected the fresh properties of SCHSC.

\section{Acknowledgments}

Authors are grateful to the Hungarian Scientific Research Fund (OTKA) for the financial support of the OTKA K 109233 research project, for Duna-Dráva Cement Kft. and SIKA Hungária Kft. for providing the materials used for the experiments, and for Dr. János Madarász (Budapest University of Technology and Economics, Department of Inorganic and Analytical Chemistry) for the X-ray tests.

\section{References}

[1] United Nations, Department of Public Information, "Agenda 21 : programme of action for sustainable development, Rio Declaration on Environment and Development, statement of forest principles: the final text of agreements negotiated by Governments at the United Nations Conference on Environment and Development (UNCED)", In: United Nations Conference on Environment \& Development, Rio de Janeiro, Brazil, 1992, pp. 3-14.

[2] The Fredonia Group, "World Construction Aggregates to 2011 - Demand and Sales Forecasts, in Market Share, Market Size, Market leaders, Industry", The Freedonia Group, Cleveland, Ohio, USA, 2011.

[3] Government of Hong Kong "Environmental Report 2006", [pdf] Hong Kong, China, 2006. Availanble at: https://www.lcsd.gov.hk/ dept/environment2006/en/index.php [Accessed: 18.01.2019]

[4] Oikonomou, N. D. "Recycled concrete aggregates", Cement and Concrete Composites, 27(2), pp. 315-318, 2005. https://doi.org/10.1016/j.cemconcomp.2004.02.020

[5] Limbachiya, M., Meddah, M. S., Ouchagour, Y. "Use of recycled concrete aggregate in fly-ash concrete", Construction and Building Materials, 27(1), pp. 439-449, 2012.

https://doi.org/10.1016/j.conbuildmat.2011.07.023

[6] Kisku, N., Joshi, H., Ansari, M., Panda, S. K., Nayak, S., Dutta, S. C. "A critical review and assessment for usage of recycled aggregate as sustainable construction material", Construction and Building Materials, 131, pp. 721-740, 2017. https://doi.org/10.1016/j.conbuildmat.2016.11.029 
[7] Meyer, C. "The greening of the concrete industry", Cement and Concrete Composites, 31(8), pp. 601-605, 2009.

https://doi.org/10.1016/j.cemconcomp.2008.12.010

[8] Omrane, M., Kenai, S., Kadri, E.-H., Ait-Mokhtar, A. "Performance and durability of self compacting concrete using recycled concrete aggregates and natural pozzolan", Journal of Cleaner Production, 165, pp. 415-430, 2017.

https://doi.org/10.1016/j.jclepro.2017.07.139

[9] Rajhans, P., Panda, S. K., Nayak, S. "Sustainable self compacting concrete from $C \& D$ waste by improving the microstructures of concrete ITZ", Construction and Building Materials, 163, pp. 557-570, 2018.

https://doi.org/10.1016/j.conbuildmat.2017.12.132

[10] Aslani, F., Ma, G., Wan, D. L. Y., Muselin, G. "Development of high-performance self-compacting concrete using waste recycled concrete aggregates and rubber granules", Journal of Cleaner Production, 182, pp. 553-566, 2018. https://doi.org/10.1016/j.jclepro.2018.02.074

[11] Wijayasundara, M., Mendis, P., Crawford, R. H. "Integrated assessment of the use of recycled concrete aggregate replacing natural aggregate in structural concrete", Journal of Cleaner Production, 174, pp. 591-604, 2018.

https://doi.org/10.1016/j.jclepro.2017.10.301

[12] Wijayasundara, M., Mendis, P., Crawford, R. H. "Methodology for the integrated assessment on the use of recycled concrete aggregate replacing natural aggregate in structural concrete", Journal of Cleaner Production, 166, pp. 321-334, 2017. https://doi.org/10.1016/j.jclepro.2017.08.001

[13] Yap, S. P., Chen, P. Z. C., Goh, Y., Ibrahim, H. A., Mo, K. H. "Characterization of pervious concrete with blended natural aggregate and recycled concrete aggregates", Journal of Cleaner Production, 181, pp. 155-165, 2018.

https://doi.org/10.1016/j.jclepro.2018.01.205

[14] Guo, S., Hu, J., Dai, Q. "A critical review on the performance of portland cement concrete with recycled organic components", Journal of Cleaner Production, 188, pp. 92-112, 2018.

https://doi.org/10.1016/j.jclepro.2018.03.244

[15] Aslani, F., Ma, G., Wan, D. L. Y., Le, V. X. T. "Experimental investigation into rubber granules and their effects on the fresh and hardened properties of self-compacting concrete", Journal of Cleaner Production, 172, pp. 1835-1847, 2018. https://doi.org/10.1016/j.jclepro.2017.12.003

[16] Vassilev, S. V., Menendez, R., Alvarez, D., Diaz-Somoano, M., Martinez-Tarazona, M. R. "Phase-mineral and chemical composition of coal fly ashes as a basis for their multicomponent utilization. 1. Characterization of feed coals and fly ashes", Fuel, 82(14), pp. 1793-1811, 2003. https://doi.org/10.1016/s0016-2361(03)00123-6

[17] Vassilev, S. V., Menendez, R., Diaz-Somoano, M., MartinezTarazona, M. R. "Phase-mineral and chemical composition of coal fly ashes as a basis for their multicomponent utilization. 2 . Characterization of ceramic cenosphere and salt concentrates", Fuel, 83(4-5), pp. 585-603, 2004. https://doi.org/10.1016/j.fuel.2003.10.003
[18] British Standards Institution "BS EN 450-1 Fly ash for concrete. Definition, specifications and conformity criteria", British Standards Institution, London, United States, 2007.

[19] Snelson, D. G., Kinuthia, J. M. "Resistance of mortar containing unprocessed pulverised fuel ash (PFA) to sulphate attack", Cement and Concrete Composites, 32(7), pp. 523-531, 2010. https://doi.org/10.1016/j.cemconcomp.2010.03.001

[20] Snelson, D. G., Kinuthia, J. M. "Characterisation of an unprocessed landfill ash for application in concrete", Journal of Environmental Management, 91(11), pp. 2117-2125, 2010.

https://doi.org/10.1016/j.jenvman.2010.04.015

[21] Hamood, A., Khatib, J. M., Williams, C. "The effectiveness of using Raw Sewage Sludge (RSS) as a water replacement in cement mortar mixes containing Unprocessed Fly Ash (u-FA)", Construction and Building Materials, 147, pp. 27-34, 2017. https://oi.org/10.1016/j.conbuildmat.2017.04.159

[22] Poon, C. S., Qiao, X. C., Lin, Z. S. "Pozzolanic properties of reject fly ash in blended cement pastes", Cement and Concrete Research, 33(11), pp. 1857-1865, 2003. https://doi.org/10.1016/S0008-8846(03)00213-8

[23] Karein, S. M. M., Joshaghani, A., Ramezanianpour, A. A., Isapour, S., Karakouzian, M. "Effects of the mechanical milling method on transport properties of self-compacting concrete containing perlite powder as a supplementary cementitious material", Construction and Building Materials, 172, pp. 677-684, 2018. https://doi.org/10.1016/j.conbuildmat.2018.03.205

[24] Jafari, H. A., Tajadini, A., Rahimi, M., Berenjian, J. "Reducing variations in the test results of self-consolidating lightweight concrete by incorporating pozzolanic materials", Construction and Building Materials, 166, pp. 889-897, 2018. https://doi.org/10.1016/j.conbuildmat.2018.01.121

[25] Rashad, A. M. "A synopsis about perlite as building material - A best practice guide for Civil Engineer", Construction and Building Materials, 121, pp. 338-353, 2016. https://doi.org/10.1016/j.conbuildmat.2016.06.001

[26] Darweesh, H. H. M. "Utilization of perlite rock in blended cementPart I: Physicomechanical properties", Direct Research Journal of Chemistry and Material Science (DRCMS), 2(1), pp. 1-12, 2014. [online] Available at: https://directresearchpublisher.org/wp-content/uploads/2015/07/Darweesh.pdf [Accessed: 18.01.2019]

[27] Yu, L.-H., H. Ou, Lee, L.-L. "Investigation on pozzolanic effect of perlite powder in concrete", Cement and Concrete Research, 33(1), pp. 73-76, 2003. https://doi.org/10.1016/S0008-8846(02)00924-9

[28] El Mir, A. Nehme, S. G. "Utilization of industrial waste perlite powder in self-compacting concrete", Journal of Cleaner Production, 156, pp. 507-517, 2017. https://doi.org/10.1016/j.jclepro.2017.04.103

[29] Magyar Szabványügyi Testület "MSZ EN 196-2 Cement testing methods. Part 2: Chemical analysis of cement", Magyar Szabványügyi Testület, Budapest, Hungary, 2013. (in Hunarian)

[29] Magyar Szabványügyi Testület "MSZ EN 525-12 Chemical analysis of cement. Part 12: Determination of free lime content", Magyar Szabványügyi Testület, Budapest, Hungary, 2014. (in Hunarian) 
[30] British Standards Institution "BS EN 12620:2002+A1 Aggregates for concrete", London, United Kingdom, 2008.

[31] Mucsi, G., B. Csőke "Power Plant Fly Ash as a Valuable Raw Material", Geosciences and Engineering, 1(1), pp. 223-236, 2012. [online] Available at: https://matarka.hu/koz/ISSN_2063-6997/ Vol1_No1/ISSN_2063-6997_vol_1_no_1_2012_eng_223-236.pdf [Accessed: 18.01.2019]

[32] González-Taboada, I. González-Fonteboa, B., Martínez-Abella, F. Seara-Paz, S. "Analysis of rheological behaviour of self-compacting concrete made with recycled aggregates", Construction and Building Materials, 157, pp. 18-25, 2017. https://doi.org/10.1016/j.conbuildmat.2017.09.076

[33] EFNARC "Specifications and guidlines for self-compacting concrete", [pdf] European Federation of National Associations Representing for Concrete, Farnham, Surrey, United Kingdom, 2002. Available at: http://www.efnarc.org/pdf/SandGforSCC.PDF [Accessed: 1801 2019]

[34] Silva, Y. F., Robayo, R. A., Mattey, P. E. Delvasto, S. "Properties of self-compacting concrete on fresh and hardened with residue of masonry and recycled concrete", Construction and Building Materials, 124, pp. 639-644, 2016. https://doi.org/10.1016/j.conbuildmat.2016.07.057

[35] Safiuddin, M. D., Salam, M. A., Jumaat, M. Z. "Effects of recycled concrete aggregate on the fresh properties of self-consolidating concrete", Archives of Civil and Mechanical Engineering, 11(4), pp. 1023-1041, 2011

https://doi.org/10.1016/S1644-9665(12)60093-4

[36] Sabet, F. A., Libre, N. A., Shekarchi, M. "Mechanical and durability properties of self consolidating high performance concrete incorporating natural zeolite, silica fume and fly ash", Construction and Building Materials, 44, pp. 175-184, 2013. https://doi.org/10.1016/j.conbuildmat.2013.02.069

[37] Khan, A. A., Sengupta, R. "Simple Circuit For Quick and Accurate Determination of Thermistor-Constant", Research and Industry, 29(1), pp. 17-19, 1984. [online] Available at: https://www. researchgate.net/publication/291462109_SIMPLE_CIRCUIT_ FOR_QUICK_AND_ACCURATE_DETERMINATION_OF_ THERMISTOR-CONSTANTS [Accessed: 18.01.2019]

[38] Safiuddin, M., West, J. S., Soudki, K. A. "Hardened properties of self-consolidating high performance concrete including rice husk ash", Cement and Concrete Composites, 32(9), pp. 708-717, 2010. https://doi.org/10.1016/j.cemconcomp.2010.07.006

[39] Etxeberria, M., Vázquez, E., Marí, A., Barra, M. "Influence of amount of recycled coarse aggregates and production process on properties of recycled aggregate concrete", Cement and Concrete Research, 37(5), pp. 735-742, 2007. https://doi.org/10.1016/j.cemconres.2007.02.002

[40] Kou, S.-C., Poon, C.-S. "Effect of the quality of parent concrete on the properties of high performance recycled aggregate concrete", Construction and Building Materials, 77, pp. 501-508, 2015. https://doi.org/10.1016/j.conbuildmat.2014.12.035

[41] Tam, V. W. Y., Tam, C. M., Wang, Y. "Optimization on proportion for recycled aggregate in concrete using two-stage mixing approach", Construction and Building Materials, 21(10), pp. 19281939, 2007.

https://doi.org/10.1016/j.conbuildmat.2006.05.040
[42] González-Fonteboa, B., Martínez-Abella, F. "Concretes with aggregates from demolition waste and silica fume", Materials and mechanical properties". Building and Environment, 43(4), pp. 429-437, 2008. https://doi.org/10.1016/j.buildenv.2007.01.008

[43] Limantono, H., Ekaputri, J. J., Susanto, T. E. "Effect of silica fume and glass powder on high-strength paste", Key Engineering Materials, 673, pp. 37-46, 2016.

https://doi.org/10.4028/www.scientific.net/KEM.673.37

[44] Dilbas, H., Şimşek, M., Çakır, Ö. "An investigation on mechanical and physical properties of recycled aggregate concrete (RAC) with and without silica fume", Construction and Building Materials, 61, pp. 50-59, 2014. https://doi.org/10.1016/j.conbuildmat.2014.02.057

[45] Oner, A., Akyuz, S., Yildiz, R. "An experimental study on strength development of concrete containing fly ash and optimum usage of fly ash in concrete", Cement and Concrete Research, 35(6), pp. 11651171, 2005. https://doi.org/10.1016/j.cemconres.2004.09.031

[46] Dabhade, A. N., Choudhari, S. R., Gajbhiye, A. R. "Performance evaluation of recycled aggregate used in concrete", International Journal of Engineering Research and Applications, 2(4), pp. 1387-1391, 2012. [online] Available at: http://www.ijera.com/papers/Vol2_issue 4/ HW2413871391.pdf [Accessed: 22.01.2019]

[47] Fonseca, N., de Brito, J., Evangelista, L. "The influence of curing conditions on the mechanical performance of concrete made with recycled concrete waste", Cement and Concrete Composites, 33(6), pp. 637-643, 2011. https://doi.org/10.1016/j.cemconcomp.2011.04.002

[48] Manzi, S., Mazzotti, C., Chiara Bignozzi, M. C. "Self-compacting concrete with recycled concrete aggregate: Study of the long-term properties", Construction and Building Materials, 157, pp. 582-590, 2017. https://doi.org/10.1016/j.conbuildmat.2017.09.129

[49] Rahal, K. "Mechanical properties of concrete with recycled coarse aggregate", Building and Environment, 42(1), pp. 407-415, 2007. https://doi.org/10.1016/j.buildenv.2005.07.033

[50] Kou, S.-C., Poon, C.-S. "Mechanical properties of 5-year-old concrete prepared with recycled aggregates obtained from three different sources", Magazine of Concrete Research, 60(1), pp. 57-64, 2008. https://doi.org/10.1680/macr.2007.00052

[51] Katz, A. "Properties of concrete made with recycled aggregate from partially hydrated old concrete", Cement and Concrete Research, 33(5), pp. 703-711, 2003. https://doi.org/10.1016/S0008-8846(02)01033-5

[51] Poon, C. S., Shui, Z. H., Lam, L. "Effect of microstructure of ITZ on compressive strength of concrete prepared with recycled aggregates", Construction and Building Materials, 18(6), pp. 461-468, 2004. https://doi.org/10.1016/j.conbuildmat.2004.03.005

[52] Poon, C. S., Shui, Z. H., Lam, L., Fok, H., Kou, S. C. "Influence of moisture states of natural and recycled aggregates on the slump and compressive strength of concrete", Cement and Concrete Research, 34(1), pp. 31-36, 2004. https://doi.org/10.1016/S0008-8846(03)00186-8

[53] de Oliveira, M. B., Vazquez, E. "The influence of retained moisture in aggregates from recycling on the properties of new hardened concrete", Waste Management, 16(1-3), pp. 113-117, 1996. https://doi.org/10.1016/S0956-053X(96)00033-5 
[54] Abd Elhakam, A., Mohamed, A. E., Awad, E. "Influence of self-healing, mixing method and adding silica fume on mechanical properties of recycled aggregates concrete", Construction and Building Materials, 35, p. 421-427, 2012. https://doi.org/10.1016/j.conbuildmat.2012.04.013

[55] Nassar, R.-U.-D., Soroushian, P. "Strength and durability of RAC containing milled glass as partial replacement for cement", Construction and Building Materials, 29, p. 368-377, 2012. https://doi.org/10.1016/j.conbuildmat.2011.10.061

[56] Kou, S. C., Poon, C. S. "Enhancing the durability properties of concrete prepared with coarse recycled aggregate", Construction and Building Materials, 35, pp. 69-76, 2012. https://doi.org/10.1016/j.conbuildmat.2012.02.032

[57] Kou, S.-C., Poon, C.-S. "Long-term mechanical and durability properties of recycled aggregate concrete prepared with the incorporation of fly ash", Cement and Concrete Composites, 37, pp. 12-19, 2013. https://doi.org/10.1016/j.cemconcomp.2012.12.011

[58] Padmini, A. K., Ramamurthy, K., Mathews, M. S. "Influence of parent concrete on the properties of recycled aggregate concrete", Construction and Building Materials, 23(2), pp. 829-836, 2009. https://doi.org/10.1016/j.conbuildmat.2008.03.006
[59] Kou, S. C., Poon, C. S. "Properties of self-compacting concrete prepared with coarse and fine recycled concrete aggregates", Cement and Concrete Composites, 31(9), pp. 622-627, 2009. https://doi.org/10.1016/j.cemconcomp.2009.06.005

[60] Yang, K.-H., Chung, H.-S., Ashour, A. F. "Influence of Type and Replacement Level of Recycled Aggregates on Concrete Properties", ACI Materials Journal, 105(3), pp. 289-296, 2008. [online] Available at: https://bradscholars.brad.ac.uk/handle/10454/7768 [Accessed 22.01.2019]

[61] Corinaldesi, V., Moriconi, G. "Influence of mineral additions on the performance of $100 \%$ recycled aggregate concrete", Construction and Building Materials, 23(8), pp. 2869-2876, 2009. https://doi.org/10.1016/j.conbuildmat.2009.02.004

[62] Pereira, P., Evangelista, L., de Brito, J. "The effect of superplasticizers on the mechanical performance of concrete made with fine recycled concrete aggregates", Cement and Concrete Composites, 34(9), pp. 1044-1052, 2012. https://doi.org/10.1016/j.cemconcomp.2012.06.009

[63] Mukharjee, B. B. Barai, S. V. "Influence of Nano-Silica on the properties of recycled aggregate concrete", Construction and Building Materials, 55, p. 29-37, 2014. https://doi.org/10.1016/j.conbuildmat.2014.01.003 